\title{
STRATEGI BISNIS HOTEL DAN RESORT \\ BERKONSEP MONGOLIAN-APACHE EXPERIENCE DI BOGOR 2018 - 2021
}

\author{
M. Akhsanur Rofi \\ PPM School of Management \\ rof@ppm-manajemen.ac.id \\ Johannes C Santoso \\ PPM School of Management \\ j.christian.santoso@gmail.com
}

\begin{abstract}
ABSTRAK
Kota Bogor tumbuh sebagai pusat wisata dan ekonomi kreatif yang semakin menarik dan kompetitif. Hotel dan Resort ME (HRME) berkonsep ala Mongolian-Apache di kaki Gunung Salak menyasar wisatawan kelas menengah-atas, korporat, \& instansi. Namun selama 5 tahun pertama, tingkat okupansirata-rata hanya 37,2\% dan profitabilitas hanya 7,9\% dari pendapatan, sementara kondisi persaingan meninggi. Tujuan penelitian adalah menyusun strategi untuk memaksimalkan potensi yang dimiliki HRME dengan formulasi yang dikembangkan David (2011). Studi eksploratori ini dilakukan dengan 3 tahap aktivitas, dimulai dari input melalui analis is eksternal makro dan industri dan analisis internal melalui RBV dan Value Chain hingga terbentuk KSF, CPM, dan Matriks IE. Aktivitas kedua yakni matching, adalah penyusunan TOWS sesuai arahan visi-misi. Aktivitas terakhir adalah memilih strategi serta menyusun peta strategi periode 2018-2019. Wawancara \& diskusi konsensus dengan pemilik dan manajemen HRME dilaksanakan, disertai observasi langsung di lapangan. Pun didukung data sekunder dari tahun 2008-2017. Diyakini, pengembangan kualitas dan sistem modal insani untuk mendukung produk/jasa hotel serta penguatan pers pektif internal dan pelanggan dalam mendukung penetrasi pasar menjadi kunci perbaikan tingkat okupansi hingga $45 \%$ dan profitabilitas hingga $15 \%$.
\end{abstract}

Kata kunci:

Hotel Resort, Wisata, Bogor, Strategi, RBV, Value Chain 


\section{PENDAHULUAN}

HRME adalah resort indah di kaki Gunung Salak dengan fasilitas hotel bintang empat berkonsep outdoor mewah bertema Mongolian dan Apache camps satu-satunya di Indonesia. Mulai beroperasi tahun 2011 di lokasi Kawasan Wisata Gunung Salak Endah, Desa Sukajadi, Bogor, HRME adalah ikon baru di kawasan tersebut. Kapasitas yang tersedia adalah 48 Mongolian Style Camps, 27 Apache Camps, 4 Mongolian Barracks, 2 Apache Barracks, dan 4 Tree Houses. Termasuk pula berbagai sarana lain untuk mendukung 4 kategori produk/jasa yang ditawarkan yakni penginapan, restoran, sarana MICE, serta sarana olahraga - outing - outbound.

Potensi HRME semakin menarik dengan lokasinya yang masih dalam jangkauan pusat wisata utama seperti Istana dan Kebun Raya Bogor, Curug Cinangka dan Luhur, tracking Gunung Salak, Kampung Budaya Sunda Sindang Barang, serta Pura Jagatkarta. Sementara itu, jumlah wisatawan Kota Bogor mencapai 5,2 juta pada tahun 2016 dan prakiraan 5,5 juta - 5,7 juta pada tahun 2017 dengan rata-rata wisatawan yang menginap di hotel/penginapan mencapai $75 \%$ (Nurhayati, 2017) dan (Disparbud, 2016).

Terdapat sekitar 212 hotel dan penginapan di wilayah Bogor pada tahun 2017, dengan 20 hotel berbintang 4, 30 hotel berbintang 3, 16 hotel berbintang 2, 76 hotel berbintang 1, dan sisanya tak berbintang (Traveloka, n.d.).

Tabel 1.

Perkembangan Kunjungan Wisatawan ke Kota Bogor Periode 2008-2016

\begin{tabular}{|l|r|r|r|r|r|r|}
\hline \multirow{2}{*}{ Tahun } & \multicolumn{3}{|c|}{ Kunjungan ke Obyek Wisata } & \multicolumn{3}{c|}{ Menginap di Hotel } \\
\cline { 2 - 3 } & \multicolumn{2}{|c|}{ Wisatawan } & \multirow{2}{*}{ Jumlah } & \multicolumn{2}{c|}{ Wisatawan } & \multirow{2}{*}{ Jumlah } \\
\cline { 2 - 3 } \cline { 6 - 7 } & Nusantara & Mancanegara & & Nusantara & \multicolumn{1}{c|}{ Mancanegara } & \\
\hline 2008 & 1.370 .119 & 18.174 & 1.388 .293 & 716.807 & 31.443 & 748.250 \\
\hline 2009 & 1.163 .110 & 42.377 & 1.205 .487 & 1.086 .374 & 102.737 & 1.189 .111 \\
\hline 2010 & 1.524 .044 & 42.812 & 1.566 .856 & 1.205 .628 & 104.076 & 1.309 .704 \\
\hline 2011 & 1.630 .687 & 43.837 & 1.674 .524 & 1.309 .875 & 106.137 & 1.416 .012 \\
\hline 2012 & 1.775 .580 & 110.975 & 1.886 .555 & 1.426 .263 & 104.223 & 1.530 .486 \\
\hline 2013 & 3.277 .442 & 104.780 & 3.382 .222 & 1.632 .657 & 99.446 & 1.732 .103 \\
\hline 2014 & 4.148 .650 & 202.280 & 4.350 .930 & 2.896 .749 & 124.108 & 3.020 .857 \\
\hline
\end{tabular}


Tabel 1. (Lanjutan)

Perkembangan Kunjungan Wisatawan ke Kota Bogor Periode 2008-2016

\begin{tabular}{|l|r|r|r|r|r|r|}
\hline \multirow{3}{*}{ Tahun } & \multicolumn{3}{|c|}{ Kunjungan ke Obyek Wisata } & \multicolumn{3}{c|}{ Menginap di Hotel } \\
\cline { 2 - 3 } & \multicolumn{2}{|c|}{ Wisatawan } & \multirow{2}{*}{ Jumlah } & \multicolumn{2}{|c|}{ Wisatawan } & \multirow{2}{*}{ Jumlah } \\
\cline { 2 - 3 } \cline { 5 - 6 } & Nusantara & Mancanegara & & Nusantara & Mancanegara & \\
\hline \multirow{2}{*}{2015} & 4.563 .516 & 222.507 & 4.786 .023 & 3.422 .637 & 166.880 & 3.589 .517 \\
\hline \multirow{2}{*}{2016} & 5.017 .578 & 244.646 & 5.262 .224 & 3.763 .184 & 183.485 & 3.946 .668 \\
\hline
\end{tabular}

Sumber: Dinas Kebuday aan, Pariwisata Kota Bogor (Disparbud, 2016)

Tabel 2.

Statistik Penerimaan Kamar HRME Periode 2011-2015

\begin{tabular}{|l|r|r|r|r|r|}
\hline & \multicolumn{1}{|c|}{$\mathbf{2 0 1 1}$} & $\mathbf{2 0 1 2}$ & $\mathbf{2 0 1 3}$ & $\mathbf{2 0 1 4}$ & \multicolumn{1}{c|}{$\mathbf{2 0 1 5}$} \\
\hline Kamar Tersedia & 12.011 & 14.895 & 18.980 & 19.925 & 27.618 \\
\hline Kamar Terpakai & 3.289 & 6.344 & 7.386 & 8.059 & 10.099 \\
\hline Okupansi & $27,00 \%$ & $43,00 \%$ & $39,00 \%$ & $40,00 \%$ & $37,00 \%$ \\
\hline Kamar Terbayar & 3.121 & 6.113 & 7.189 & 7.949 & 9.850 \\
\hline \% Okupansi Pembayaran & $95 \%$ & $96 \%$ & $97 \%$ & $99 \%$ & $98 \%$ \\
\hline Penggunaan Rumah & 14 & 0 & 1 & 5 & 11 \\
\hline Kamar Komplimentari & 168 & 226 & 194 & 105 & 238 \\
\hline Kamar Tak Tergunakan & 592 & 43 & 1 & 61 & 567 \\
\hline Jumlah Tamu & 14.586 & 30.374 & 36.746 & 42.164 & 51.169 \\
\hline
\end{tabular}

Sumber: Data internal perusahaan, 2017

Jumlah yang besar ini mendorong persaingan harga dan promosi gencar di industri perhotelan Bogor. Semakin banyaknya pendatang baru mendorong tingkat okupansi rata-rata perhotelan menurun dan turut menekan profitabilitas industri. CAGR pertumbuhan hotel di Bogor mencapai $40 \%$ dari tahun 2011-2016 (Indonesia Hotel Watch, 2016), jauh lebih tinggi dari CAGR pertumbuhan wisatawan yang menginap yakni sekitar $23 \%$.

Dalam skala nasional, total kamar usaha akomodasi mencapai 353.138 (2010) meningkat $165 \%$ menjadi 582.353 (2016). Tingkat okupansi kamar nasional berkisar antara 50\% - 55\% atau $45 \%-55 \%$ untuk wilayah Jabar selama tahun tersebut (BPS, n.d.) dan (Kemenpar, n.d.). Kelompok Sahira Group di Bogor bahkan dapat mencapai 80\% (Prayoga, 2017) sementara rata-rata di kawasan Bogor mencapai 60\% (Herlambang, 2016).

Tingkat okupansi HRME hanya $37 \%$ pada tahun 2015, sangat rendah dan jauh dari target, padahal konsep yang ditawarkan sangat unik ala Mongolian \& Apache Camp berbeda dari kompetitor lain, serta memiliki fasilitas 


\section{PERSENTASE B IAYA HRME 2015}

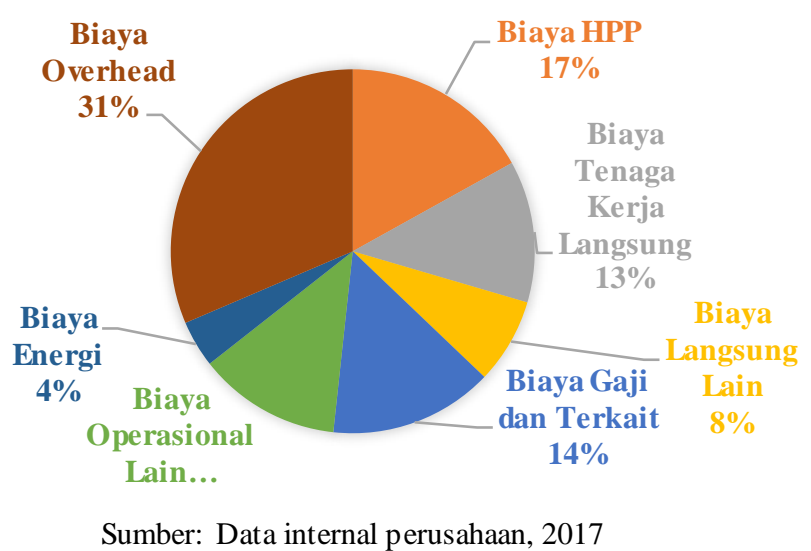

Gambar .1

Persentase Komponen Biaya HRME 2015

lengkap dan berkelas. Dengan tingkat okupansi rendah, manajemen harus melakukan usaha ekstra untuk mengimbangi biaya tetap overhead perawatan rutin camp dan utilisasi SDM

Dampak lain dari rendahnya tingkat okupansi adalah menurunnya profitabilitas. Dari data yang diperoleh langsung, pendapatan per tahun dari resort $\mathrm{HRME}$ masih minim, di bawah dari target harapan manajemen (hanya mencapai 88\%). Namun karena keterbatasan manajemen, analisis lebih lanjut untuk identifikasi masalah ini belum pernah dilakukan.

Daridata internal tahun 2015 diketahui persentase laba bersih (owner share profit) hanya $7,9 \%$ dari total pendapatan. Hal ini diakibatkan peningkatan biaya tenaga kerja

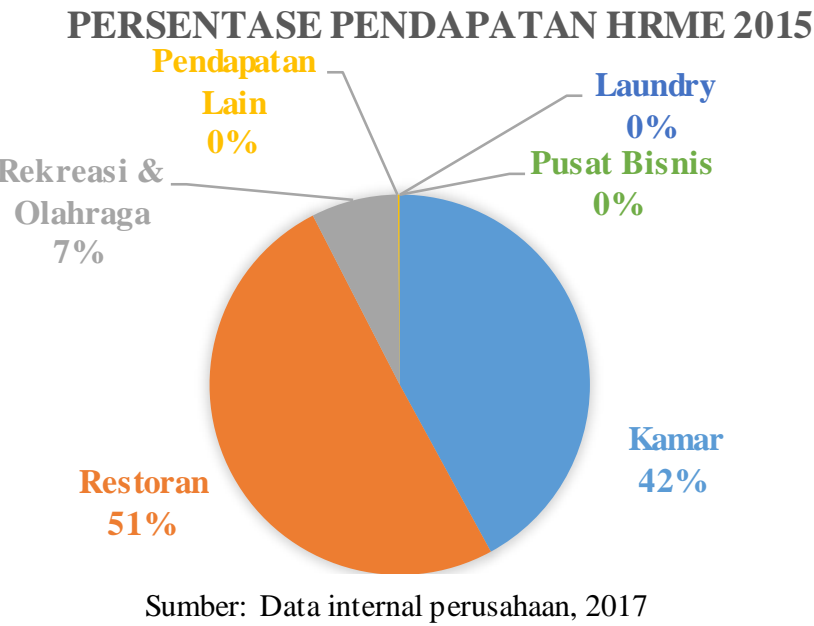

Gambar 2.

Persentase Pendapatan HRME 2015

langsung sebesar 50\%, biaya langsung lain sebesar $14 \%$, biaya tenaga kerja tak langsung $40 \%$, biaya energi $64 \%$, serta biaya overhead 44\% (semua dihitung berbasis budget 2015).

Data internal juga menunjukkan bahwa tingkat penerimaan pendapatan tidak maksimal, pendapatan kamar hanya tercapai 94\%, restoran dan rekreasi-olahraga lebih rendah yakni $82 \%$ dan $90 \%$, sedangkan laundry dan pusat bisnis lebih rendah lagi yakni hanya $23 \%$.

Dari situasi di atas, maka dirumuskan masalah utama HRME, yakni: (1) Bagaimana posisi HRME dalam analisis internal dan eksternal pada masa kini dan mendatang ; (2) Bagaimana rancangan strategi bisnis yang sesuai. Tujuan penelitian ini adalah menilai kembali posisi perusahaan, serta menghasilkan 
rancangan inisiatif guna meningkatkan okupansi dan profitabilitas perusahaan. Tentunya riset serupa dapat memperoleh manfaat dari bagaimana riset ini disusun, serta analisis industrial yang dapat dimanfaatkan sebagai perbandingan.

\section{TINJAUAN TEORI}

David (2011) mengatakan bahwa manajemen strategi adalah seni \& ilmu memformulasi, mengimplementasi, mengevaluasi keputusan lintas fungsi yang memungkinkan organisasi mencapai tujuan. Penelitian ini berada pada tahap pertama yakni formulasi strategi yang terbagi atas aktivitas input, matching, dan decision. Aktivitas input memadukan hasil asesmen internal-eksternal ke faktor prioritas, faktor penentu keberhasilan, serta posisi relatif atas kompetitor. Aktivitas matching adalah penyesuaian hasil aktivitas input terhadap arahan visi, misi, dan kepentingan pemangku bisnis ke dalam matriks TOWS dan matriks IE. Sedangkan, aktivitas akhir berupa pengambilan keputusan melalui penyusunan tabel QSPM.

Strategi didasarkan pada pemenuhan visi-misi perusahaan. Menurut Wibisono
(2006), visi merupakan rangkaian kalimat yang menyatakan cita atau impian organisasi di masa depan. Sedangkan menurut Drucker (2008), misi merupakan alasan mendasar eksistensi suatu organisasi, terutama di tingkat unit bisnis untuk menentukan batas dan maksud aktivitas.

Analisis eksternal diperlukan untuk memahami posisi perusahaan, juga untuk memahami kebutuhan pelanggan, pergolakan perubahan, serta rantai nilai (Schonberger, 1997). Porter \& Magretta (2014) menggunakan analisis kekuatan kompetitor, pendatang baru, produk subtitusi, daya tawar pemasok, dan daya tawar pembeli untuk mengamati kekuatan dan perubahan eksternal. Besaran pengaruh faktor industrial ini mempengaruhi kemampulabaan sekaligus kunci kesuksesan bersaing. Sementara itu, Sammut-Bonnici \& Galea (2015) memandang bahwa analisis makro menggunakan PESTEL adalah efektif sebagai alat bantu memahami risiko strategis yang akan mempengaruhi model bisnis dari perspektif resources, capabilities, dan core competence. Key success factors (KSF) merupakan implikasi pencocokan organisasi-lingkungan, sebagai area yang berpotensi bagi perusahaan untuk memperoleh competitive advantage pada 
suatu industri. KSF dapat ditelusuri dari faktor

Quality, Cost, Delivery, Speed, Flexibility, Innovation (David \& David, 2014).

Sedangkan Critical Success Factors

(CSF) merupakan faktor internal yang menentukan keberhasilan dalam memenuhi KSF. CSF selanjutnya menjadi komponen Competitive Profile Matrix (CPM) sebagai alat ukur perbandingan. Semakin tinggi nilai CSF, semakin kuat posisi dan strategi organisasi (David \& David, 2014).

$$
\text { Barney (1991) melalui konsep }
$$

Resources Based View (RBV) berargumen bahwa sumber daya ikut menentukan keberlangsungan organisasi. Strategi tidak hanya ditentukan dari posisi di industri, namun juga kekuatan resources yang dimilikinya, yakni sumber daya (atau aset) fisik (pabrik, gedung, lokasi, dan teknologi), aset manusia (jumlah dan kecakapan karyawan) serta aset organisasi seperti budaya, reputasi, dan sistem kerja (Amir, 2011).

Organisasi dipandang sebagai sumber daya \& kemampuan yang dapat dikonfigurasi untuk membangun keunggulan kompetitif (Henry, 2007). Wernerfelt (1984) melihat sumber daya tangible maupun intangible bisa menjadi kekuatan/kelemahan perusahaan, sekaligus sumber keunggulan unik. Identifikasi ketidakmampuan pesaing untuk meniru sumber daya dapat dianalisis melalui konsep RBV sehingga penting menggunakan konsep ini dalam komponen analisis internal.

Porter \& Magretta (2014) merumuskan bahwa rantai nilai perusahaan terdiri atas aktivitas primer dan pendukung. Aktivitas primer berupa logistik ke dalam (bahan baku \& pergudangan), operasi, logistik ke luar (pemasaran, penjualan, distribusi), hingga layanan konsumen. Sedangkan aktivitas pendukung terdiri dari pengadaan, teknologi, SDM, dan infrastruktur strategi/keuangan. Analisis ini berguna dalam mengevaluasi apakah sumber daya unik internal dimanfaatkan untuk nilai tambah.

Matriks IE yang terbagi dalam 9 blok memberikan pilihan strategi berbeda setelah asesmeninternal-eksternal dilakukan. Keluaran IE kemudian dirincikan dalam diagram TOWS (David, 2011).

Diagram TOWS memunculkan 4 jenis strategi. Strategi SO (Strengths-Opportunities) adalah jenis strategi yang menggunakan kekuatan organisasi dalam pemanfaatan kesempatan. Strategi ST (Strengths-Threats) adalah strategi penggunaan kekuatan internal 
atas ancaman eksternal. Strategi SO bersifat agresif, sedangkan strategi ST bersifat diversifikasi. Sementara itu, strategi WO (Weaknesses-Opportunities) mengurangi kelemahan internal dengan pemanfaatan peluang, sebagai turnaround strategy. Terakhir, strategi WT (Weaknesses-Threats) bersifat defensif dengan meminimalkan kelemahan internal dalam mengatasi ancaman luar.

Setelah melalui pertimbangan manajemen, terpilihlah strategi yang tertuang dalam Quantitave Strategic Planning Matrix (QSPM) dan terjabarkan rinci melalui peta strategi. Peta strategi merupakan bagian dari BSC sebagai sistem manajemen strategis yang menerjemahkan visi dan strategi ke dalam tujuan dan ukuran operasional (Hansen \&Mowen, 2003), dengan kombinasi ukuran finansial dan non-finansial (Kaplan \& Norton, 2004). Peta Strategi dan QSPM membantu deskripsi strategi menjadi lebih kohesif dan komprehensif sehingga terimplementasi dengan baik (David, 2011) \& (BSI, n.d.)

Seluruh proses yang terurai pada tinjauan teori terangkum dalam kerangka analisis pada Gambar 3 di bawah ini:

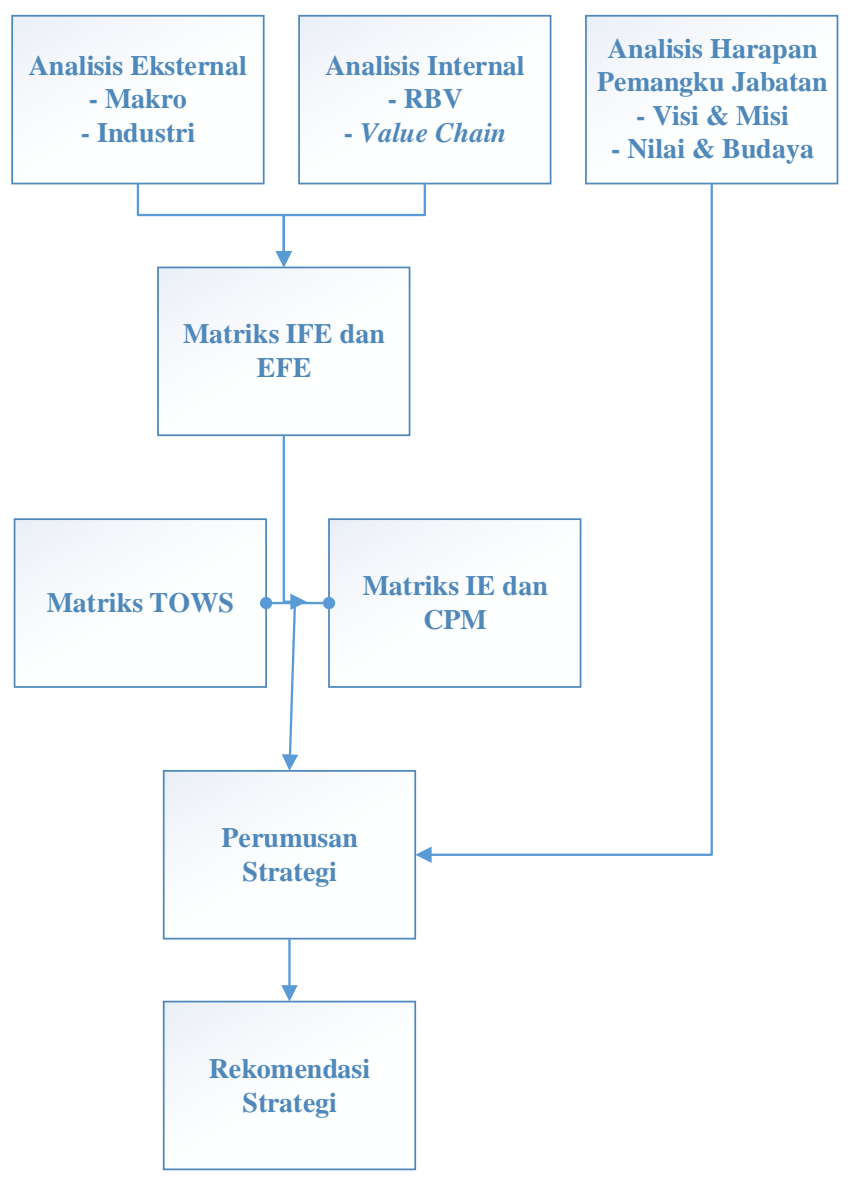

Gambar 3.

Kerangka Analis is Penelitian

\section{METODE RISET}

Penelitian ini adalah riset terapan yang berusaha memahami fenomena kontemporer teramati ke dalam sebuah problem terdefinisi melalui penemuan ide dan gagasan. Termasuk dalam kategori riset kualitatif exploratory yang memformulasikan serangkaian langkah/proses sehingga problem dapat terdefinisi dengan baik sampai terbentuk hipotesis dan rekomendasi (Zikmund et al, 2012).

Unit analisis adalah grup/organisasi, dengan subjek penelitian perusahaan HRME. 
Studi dilakukan selama satu tahun di tahun

2017. Industri didefinisikan sebagai sekumpulan pemain bisnis perhotelan dan resort berbintang 3-5 sebagai pendukung pariwisata yang melayani pelanggan di wilayah Bogor secara khusus, dan wilayah Jabodetabek secara umum.

Data yang dibutuhkan adalah data primer dari internal perusahaan yakni pemilik bisnis dan manajemen perusahaan. Data primer diolah berdasarkan pemahaman kontekstual dan konsensus yang merepresentasikan grup, bukan individu. Data ini diambil melalui wawancara dan diskusi terbuka (dengan teknik open-ended question), serta observasi langsung yang dilakukan selama waktu penelitian satu tahun 2017. Sementara itu, data sekunder berupa data industri dan konsumen yang diambil dalam periode tahun 2008-2017 yang muncul melalui studi dokumen dari buku, artikel, dan media. Proses pengolahan data terangkum pada tabel 3 .

\section{PEMBAHASAN}

\section{Profil Bisnis}

HRME bervisi menjadi resort terunik dan terlengkap di Indonesia. Lalu Misinya tertuang dalam 7 hal, yakni (1) Secara konsisten memenuhi harapan pelanggan bahkan melebihi melalui tim yang kompeten dan termotivasi mewujudkan nilai tambah; (2) Menggabungkan keramah-tamahan alami orang Indonesia, pemandangan resort, pengalaman di industri untuk pelayanan bermutu secara konsisten; (3) Dikenal lokal dan internasional melalui perbaikan terus menerus atas manajemen mutu \& keamanan pangan; (4) Memaksimalkan pendapatan melalui kompetisi secara respek; (5) Menjamin lingkungan kerja bersahabat untuk lingkungan alami; (6) Responsibilitas untuk masyarakat sekitar yang tepat sasaran; (7) Memberikan kesempatan kemajuan kepada karyawan pekerjaan guna meningkatkan mutu kehidupan. Sementara itu nilai-nilai HRME terangkum dam HIGHEST yakni Hospitality, Integrity, Genuine, Humble, Excellent, Safety, Thankful. Sedangkan struktur organisasi tertinggi dipegang oleh General Manager, dibantu 9 Manager, yang membawahi 7 departemen, yakni Front Office, $F \& B$, Accounting, Purchasing. Marketing, Housekeeping, Personnel, serta Engineering. 
Tabel 3.

Tabel Pengolahan Data

\begin{tabular}{|c|c|c|c|c|}
\hline Langkah & Kebutuhan Data & Sumber Data & Metode & Hasil \\
\hline $\begin{array}{l}\text { Analis is } \\
\text { Harapan } \\
\text { Pemangku } \\
\text { Jabatan }\end{array}$ & $\begin{array}{l}\text { Tujuan, budaya } \\
\text { dan nilai-nilai } \\
\text { yang dianut } \\
\text { perusahaan }\end{array}$ & $\begin{array}{l}\text { Direktur perusahaan, } \\
\text { Pemegang Saham }\end{array}$ & $\begin{array}{l}\text { Wawancara terbuka } \\
\text { dengan analisis } \\
\text { konteks dan } \\
\text { konsensus }\end{array}$ & $\begin{array}{l}\text { Pernyataan visi, misi, } \\
\text { budaya dan nilai } \\
\text { perusahaan } \\
\text { Sebagai pedoman } \\
\text { penetapan strategi jangka } \\
\text { menengah }\end{array}$ \\
\hline $\begin{array}{l}\text { Analisis } \\
\text { Eksternal } \\
\text { Makro }\end{array}$ & $\begin{array}{l}\text { Kondisi politik, } \\
\text { ekonomi, sosial, } \\
\text { teknologi, legal, } \\
\text { lingkungan }\end{array}$ & $\begin{array}{l}\text { Situs Badan Pusat Statistik, } \\
\text { situs Pemerintah Kota } \\
\text { Bogor, situs Kementerian } \\
\text { Kebudayaan, Pariwisata, } \\
\text { Ekonomi Kreatif }\end{array}$ & $\begin{array}{l}\text { Analis is konteks dan } \\
\text { analis is tren }\end{array}$ & $\begin{array}{l}\text { Tren makro Indonesia } \\
\text { terangkum dalam peluang } \\
\text { dan ancaman / matriks } \\
\text { EFE }\end{array}$ \\
\hline $\begin{array}{l}\text { Analisis } \\
\text { Eksternal } \\
\text { Industri }\end{array}$ & $\begin{array}{l}5 \text { kekuatan } \\
\text { Porter }\end{array}$ & $\begin{array}{l}\text { Kementerian Kebudayaan, } \\
\text { Pariwisata, Ekonomi } \\
\text { Kreatif; situs Bank } \\
\text { Indonesia, Direktur } \\
\text { Perusahaan, Pemegang } \\
\text { Saham }\end{array}$ & $\begin{array}{l}\text { Analis is konteks dan } \\
\text { analisis tren, } \\
\text { Wawancara dan } \\
\text { diskusi konsensus }\end{array}$ & $\begin{array}{l}\text { (1) Posisi HRME dalam } \\
\text { industri perhotelan; (2) } \\
\text { KSF industri perhotelan; } \\
\text { (3) Peluang dan } \\
\text { ancaman / Matriks EFE }\end{array}$ \\
\hline $\begin{array}{l}\text { Analis is } \\
\text { RBV dan } \\
\text { Rantai Nilai }\end{array}$ & $\begin{array}{l}\text { Laporan Keuangan } \\
\text { 2011-2015 \& } \\
\text { Rasio Keuangan, } \\
\text { Bisnis Proses }\end{array}$ & $\begin{array}{l}\text { Laporan keuangan 2011- } \\
2015, \text { Business Plan } 2017\end{array}$ & $\begin{array}{l}\text { Analisis rasio, } \\
\text { analisis tren, } \\
\text { observasiaktivitas, } \\
\text { wawancara }\end{array}$ & $\begin{array}{l}\text { Kekuatan dan kelemahan } \\
\text { / Matriks IFE }\end{array}$ \\
\hline $\begin{array}{l}\text { Analis is } \\
\text { TOWS }\end{array}$ & $\begin{array}{l}\text { Posisi dalam } \\
\text { industri, KSF } \\
\text { industri, peluang } \\
\text { dan ancaman, } \\
\text { kekuatan dan } \\
\text { kelemahan }\end{array}$ & $\begin{array}{l}\text { Situs Badan Pusat Statistik, } \\
\text { situs Pemerintah Kota } \\
\text { Bogor, situs Kementerian } \\
\text { Kebudayaan, Pariwisata, } \\
\text { Ekonomi Kreatif; Laporan } \\
\text { Keuangan 2011- 2015, } \\
\text { Business Plan } 2017\end{array}$ & Analis is konteks & Perumusan strategi \\
\hline $\begin{array}{l}\text { Analis is } \\
\text { IE - CPM }\end{array}$ & Matriks EFE-IFE & $\begin{array}{l}\text { Analisis Eksternal dan } \\
\text { Internal, Google Trends, } \\
\text { Agoda }\end{array}$ & Analisis konteks & $\begin{array}{l}\text { Profil perbandingan } \\
\text { kinerja }\end{array}$ \\
\hline $\begin{array}{l}\text { Perumusan } \\
\text { Strategi }\end{array}$ & $\begin{array}{l}\text { Matriks TOWS, IE, } \\
\text { CPM, dan pedoman } \\
\text { penetapan strategi } \\
\text { jangka menengah }\end{array}$ & $\begin{array}{l}\text { Laporan Keuangan 2011- } \\
2015 \text { Business Plan } 2017 \\
\text { Situs Badan Pusat Statistik, } \\
\text { situs Pemerintah Kota } \\
\text { Bogor, situs Kementerian } \\
\text { Kebudayaan, Pariwisata, } \\
\text { Ekonomi Kreatif situs Bank } \\
\text { Indonesia (BI) }\end{array}$ & $\begin{array}{l}\text { Analisis konteks, } \\
\text { Wawancara dan } \\
\text { diskusi konsensus }\end{array}$ & $\begin{array}{l}\text { Strategi terpilih jangka } \\
\text { menengah }\end{array}$ \\
\hline $\begin{array}{l}\text { Rekomendasi } \\
\text { Strategi }\end{array}$ & Strategi terpilih & $\begin{array}{l}\text { Laporan Keuangan 2011- } \\
2015 \text { Business Plan } 2017 \\
\text { Visi-Misi, Nilai \& Budaya }\end{array}$ & $\begin{array}{l}\text { Analisis konteks } \\
\text { melalui kata kunci, } \\
\text { Wawancara dan } \\
\text { diskusi konsensus }\end{array}$ & Peta Strategi \\
\hline
\end{tabular}

\section{Analisis Eksternal}

Kota Bogor memiliki lingkungan yang nyaman, aman, dan sedikit gangguan wisata. Revitalisasi situs sejarah dan peningkatan infrastruktur juga menjadi fokus pemerintah.
Sehingga Bogor memiliki peringkat tinggi

dalam kota yang dicintai masyarakatnya.

Aturan perijinan bisnis dan lainnya juga perlahan membaik (Pemerintah Kota Bogor, 2003 dan 2017). Laju inflasi selama 2012-2016 
menurun dari $4,06 \%$ ke $3,06 \%$, sementara

tingkat pertumbuhan terjaga (BPS, 2016).

Kontribusi pariwisata secara nasional semakin signifikan, mencapai 4,23\% dari PDB nasional dengan menyerap pariwisata sampai 12 juta di tahun 2015 (Kementerian Pariwisata, 2015).

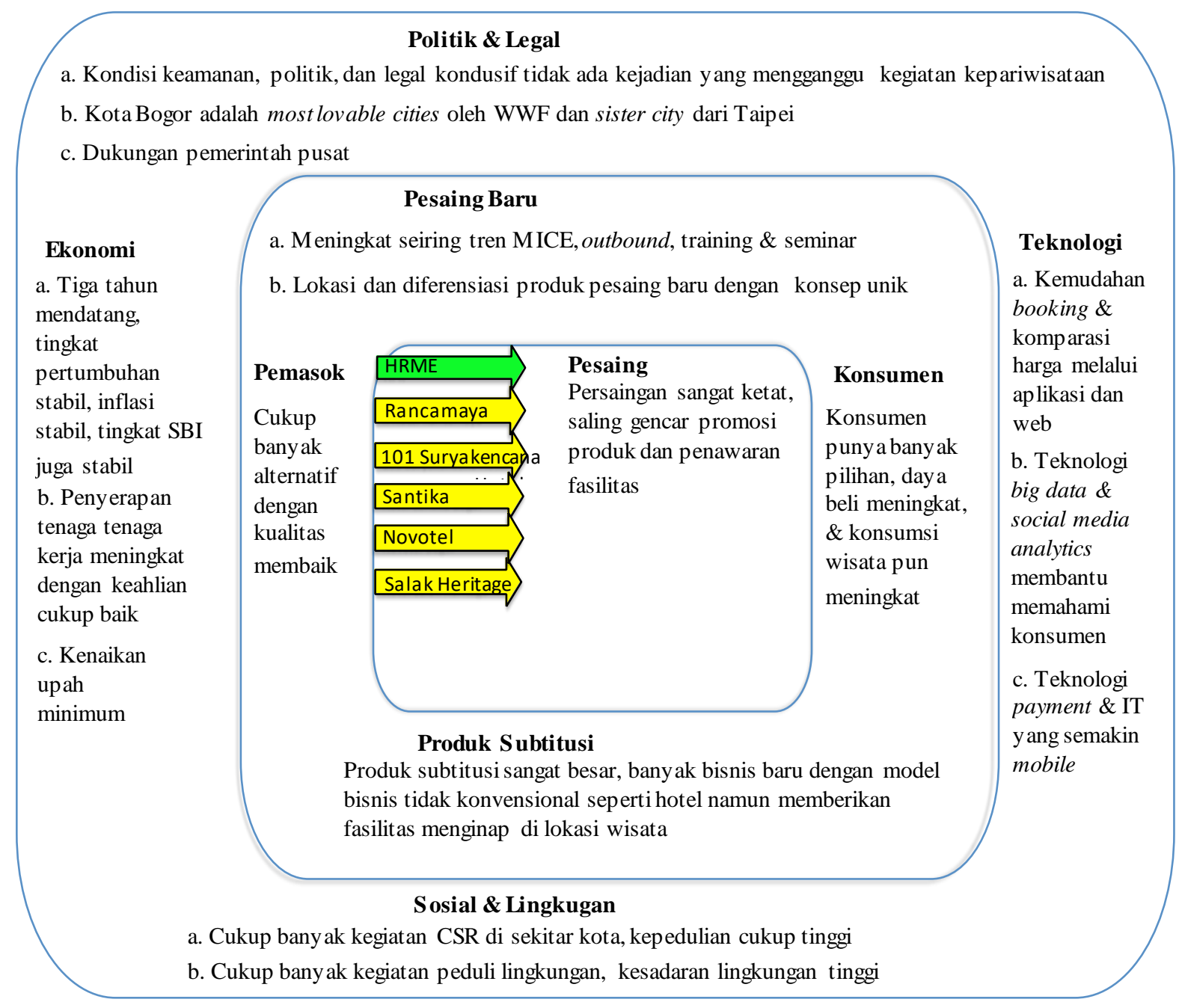

Gambar 4.

\section{Peta Analisis Makro dan Industri}

Kontribusi pariwisata yang meningkat

akan menggeser PDB sektor pertambangan,

minyak bumi, dan pertanian. Khususnya di

Kota Bogor, kontribusi pariwisata mencapai

20\%. Jika lingkungan makro terjaga baik,

kontribusi ini semakin naik. Pertumbuhan

ekonomi positif ikut mendorong kenaikan upah minimum semakin drastis, sementara tenaga

kerja berkualitas tinggi cukup sulit diperoleh.

Masyarakat kota Bogor memiliki

kepedulian sosial dan lingkungan yang cukup

baik, kegiatan pengembangan komunitas dan

CSR cukup banyak. Pusat kegiatan binaan juga

tumbuh (Pemerintah Kota Bogor, 2017). 
Pada sisi lain, teknologi mobile yang didukung big data \& social media berkembang pesat. Perusahaan semakin banyak menggunakan platform digital dalam promosi \& aktivitas bisnis operasional. Hal ini tidak hanya memudahkan konsumen, namun juga mendorong bisnis makin efisien-efektif.

Hambatan masuk industri bagi kompetitor baru cukup tinggi, selain kebutuhan modal, juga faktor lokasi, kehandalan manajemen, dan diferensiasi produk menjadi entry barrier. Namun hotel baru dan unik tetap saja tumbuh.

Pada sisi pemasok, dominasi beberapa vendor eksisting cukup kuat. Namun perusahaan bisa memilih vendor lain meski ada resiko biaya peralihan tinggi dan resiko kualitas. Beberapa kelompok pemasok tertentu memiliki kemampuan untuk melakukan integrasi vertikal, diantaranya biro perjalanan, industri penerbangan, dan vendor utilitas.

Posisi pembeli dapat dikatakan sangat kuat, Produk standar non-mewah telah menjadi pasarkomoditas yang dipenuhi sesak oleh hotel berbintang tiga dan dua. Faktor switching cost yang rendah, kemudahan informasi perbandingan harga, serta pilihan produk yang melimpah mendorong perusahaan harus kuat menanamkan diferensiasi. Pada kelompok pembeli tertentu seperti korporat, BUMN, dan pemerintah daerah, kemampuan membeli dalam jumlah relatif besar cukup tinggi.

$$
\text { Hadirnya teknologi digital serta }
$$

efisiensi akses pendanaan mendorong banyak model bisnis baru ikut masuk, seperti serviced apartment, kondominium, kondotel, termasuk model bisnis $\mathrm{AirBnB}$ dan bisnis akomodasi terselubung seperti kamar sewa dan rumah hunian.

$$
\text { Jumlah wisatawan mancanegara }
$$

mampu tumbuh 40\% CAGR dari tahun 20112016 (Kompas, 2015), hal ini mendorong hotel berbintang makin sengit dalam bersaing.

Tabel 4.

Data Hotel Berbintang di Sekitar Kaki

Gunung Salak

\begin{tabular}{|c|c|c|c|c|}
\hline $\begin{array}{c}\text { Nama } \\
\text { Hotel }\end{array}$ & $\begin{array}{c}\text { Tingkat } \\
\text { Fasilitas } \\
\text { Properti } \\
*\end{array}$ & $\begin{array}{c}\text { Rating } \\
\text { Tamu }\end{array}$ & $\begin{array}{c}\text { Rating } \\
\text { Value } \\
\text { for } \\
\text { Money }\end{array}$ & $\begin{array}{c}\text { Harga } \\
\text { Kamar** }\end{array}$ \\
\hline HRME & 4 & $\begin{array}{c}\text { Very } \\
\text { Good } 7,2 \\
(116 \\
\text { ulas an })\end{array}$ & 6,7 & $\begin{array}{c}1.082 .97 \\
5\end{array}$ \\
\hline $\begin{array}{c}\text { R Hotel } \\
\text { Rancamaya }\end{array}$ & 4 & $\begin{array}{c}\text { Excellent } \\
8,2(1068 \\
\text { ulasan })\end{array}$ & 8,0 & 911.983 \\
\hline $\begin{array}{c}\text { The 101 } \\
\text { Bogor }\end{array}$ & 4 & $\begin{array}{c}\text { Very } \\
\text { Good } 7,8 \\
(679 \\
\text { Suryakenca } \\
\text { na Hotel*** } *\end{array}$ & 7,7 & 581.818 \\
\hline $\begin{array}{c}\text { Hotel } \\
\text { Santika } \\
\text { Bogor }\end{array}$ & 4 & $\begin{array}{c}\text { Very } \\
\text { Good } 7,8 \\
(605 \\
\text { ulasan })\end{array}$ & 7,2 & 702.479 \\
\hline
\end{tabular}


Tabel 4.

Data Hotel Berbintang di Sekitar Kaki Gunung Salak (Lanjutan)

\begin{tabular}{|c|c|c|c|c|}
\hline $\begin{array}{c}\text { Nama } \\
\text { Hotel }\end{array}$ & $\begin{array}{c}\text { Tingkat } \\
\text { Fasilitas } \\
\text { Properti } \\
*\end{array}$ & $\begin{array}{c}\text { Rating } \\
\text { Tamu }\end{array}$ & $\begin{array}{c}\text { Rating } \\
\text { Value } \\
\text { for } \\
\text { Money }\end{array}$ & $\begin{array}{c}\text { Harga } \\
\text { Kamar** }\end{array}$ \\
\hline $\begin{array}{c}\text { Novotel } \\
\text { Bogor Golf } \\
\text { Resort \& } \\
\text { Convention } \\
\text { Center }\end{array}$ & 4 & $\begin{array}{c}\text { Vory } \\
\text { Good } 7,6 \\
(1404 \\
\text { ulasan })\end{array}$ & 7,4 & 776.859 \\
\hline $\begin{array}{c}\text { Hotel Salak } \\
\text { The }\end{array}$ & 4 & $\begin{array}{c}\text { Very } \\
\text { Good 7,5 } \\
(649 \\
\text { Heritage }\end{array}$ & 7,2 & 423.225 \\
\hline
\end{tabular}

kelengkerdasarkan kenya manan, fasilitas, dan ramar tidur yang diharapkan ** Harga Choice Agoda Travelers 2016 (Agoda, 2016)

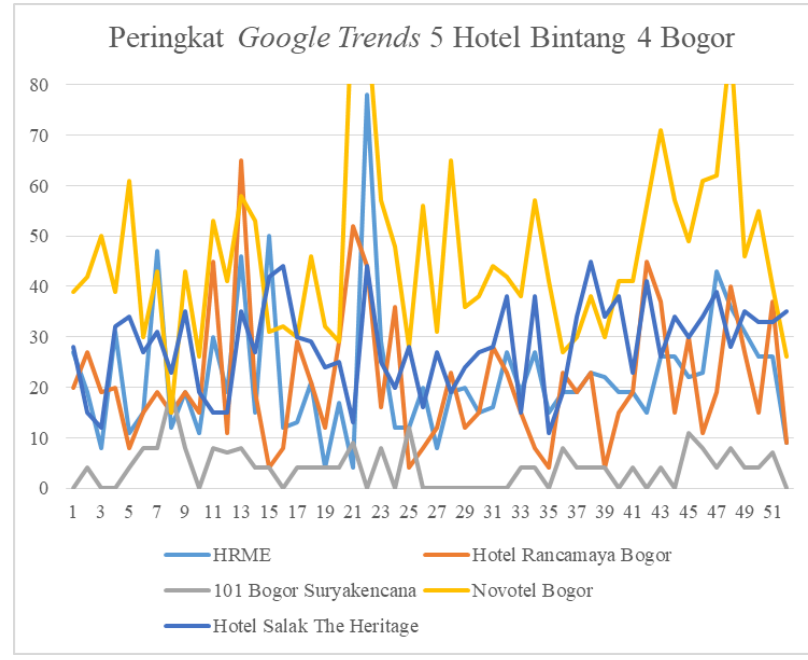

(Trends.google.com, 2018)

Gambar 5.

Peringkat Google Trends Hotel Bintang 4 di Bogor dalam 52 Minggu Tahun 2017

yang dapat dijelaskan dari Gambar 5 antara

lain: Novotel memiliki peringkat relatif tertinggi dibanding yang lain, hal ini didorong oleh brand awareness dari jaringan hotel Novotel di Indonesia yang cukup tinggi. Hotel Salak The Heritage peringkatnya di nomor dua, namun trennya semakin kuat. Dimungkinkan brand image yang dibawa oleh Hotel Salak yakni heritage khas Kota Bogor cukup berhasil. HRME yang membawa konsep outdoor berada di peringkat tiga, namun sangat dekat trennya dengan Hotel Rancamaya yang juga membawa konsep resort berciri khas golf estate. Sedangkan 101 Bogor Suryakencana berada di peringkat terbawah. Hotel ini berkonsep heritage, wisata kuliner, dan memanfaatkan kawasan Chinatown dan Kebun Raya Bogor. 
Patut dipertimbangkan bahwa Google

Trends menggunakan data yang berasal dari

konten yang dimuat online, jumlah pencarian

online, serta segala query yang berhubungan

dengan keyword tertentu. Dotson et al (2016)

memperlihatkan hubungan antara brand

attitude dengan brand search.

Diketahui pula, populasi hotel

berkonsep resort bertambah banyak selama dua

tahun terakhir, diperkirakan akan semakin

meningkat hingga 3 tahun mendatang.

Tabel 5.

Hotel Berkonsep Resort \& Outdoor di Wilayah Bogor

\begin{tabular}{|c|c|}
\hline Hotel & Konsep \\
\hline HRME & $\begin{array}{l}\text { Camping, treehouse, } \\
\text { barrack resort \& outdoor }\end{array}$ \\
\hline R Hotel Rancamaya & Golf estate \& playground \\
\hline Aston Bogor Hotel & Urban culinary \\
\hline $\begin{array}{l}\text { Aston Sentul Lake } \\
\text { Resort }\end{array}$ & Modern retreat resort \\
\hline $\begin{array}{l}\text { Pesona Alam Resort } \\
\& \text { Spa }\end{array}$ & Natural retreat resort \\
\hline $\begin{array}{l}\text { Plataran Puncak } \\
\text { Villa }\end{array}$ & $\begin{array}{l}\text { Private villa \& gazebo } \\
\text { resort }\end{array}$ \\
\hline $\begin{array}{l}\text { Jambuluwuk } \\
\text { Boutique Resort }\end{array}$ & Ethnic jungle resort \\
\hline $\begin{array}{l}\text { Royal Tulip Gunung } \\
\text { Geulis }\end{array}$ & Golf estate \& playground \\
\hline Padjajaran Suites & Downtown retreat resort \\
\hline JSI Resort & Ethnic resort \\
\hline $\begin{array}{l}\text { Safari Lodge } \\
\text { Puncak }\end{array}$ & $\begin{array}{l}\text { African safari in caravan, } \\
\text { bungalow resort }\end{array}$ \\
\hline Novotel Bogor & Golf estate \\
\hline $\begin{array}{l}\text { Talita Mountain } \\
\text { Resort }\end{array}$ & Romantic retreat \\
\hline Citra Cikopo & chalet cabin retreat \\
\hline Grand Hill Bistro & Bali style resort \\
\hline Puncak Pass Resort & Heritage resort \\
\hline $\begin{array}{l}\text { Pinewood Lodge \& } \\
\text { Organic Farm }\end{array}$ & European \& agri resort \\
\hline Khansa Resort & Agri resort \\
\hline
\end{tabular}

Tabel di atas memberikan gambaran bahwa tingkat persaingan hotel resort semakin ketat. Nilai keunikan yang ditawarkan tidak cukup hanya menjadi pendorong calon pelanggan untuk membeli produk/jasa.

Daya tarik industri perhotelan di Bogor adalah sedang ke rendah hingga 3 tahun mendatang. Analisis Porter menunjukkan bahwa intensitas persaingan, ancaman produk pengganti, dan daya tawar konsumen juga tinggi. Ruang untuk bertahan diperoleh dari entry barrier dan daya tawar pemasok.

Terdapat $7 \mathrm{KSF}$ yang teridentifikasi yakni: kualitas pelayanan konsisten tinggi, sumber daya manusia profesional terstandar perhotelan, lokasi, fasilitas berkelas, unik, instagrammable, harga kompetitif, jaringan hotel dengan penawaran variatif, keuangan untuk modal kerja dan investasi, serta standar terakreditasi.

Melalui Matriks EFE, tersusun 19 faktor ekternal dengan 9 peluang dan 9 ancaman dengan total skor 2.87. Skor ini menjelaskan kemampuan perusahaan dalam merespon situasi eksternal yang mana berada di bawah angka 3 (di atas rata-rata) atau 4 (superior). Respon berdampak terbesar yang 
dapat dilakukan oleh HRME pemanfaatan lokasi hotel, dengan menawarkan paket harga menarik untuk segmen pelanggan grup, dan aktif melakukan promosi pada situs online booking serta media sosial, serta terus melakukan inovasi nilai tambah. Sementara itu, peluang lebih banyak muncul pada faktor makro, sedangkan ancaman lebih banyak muncul pada faktor industri.

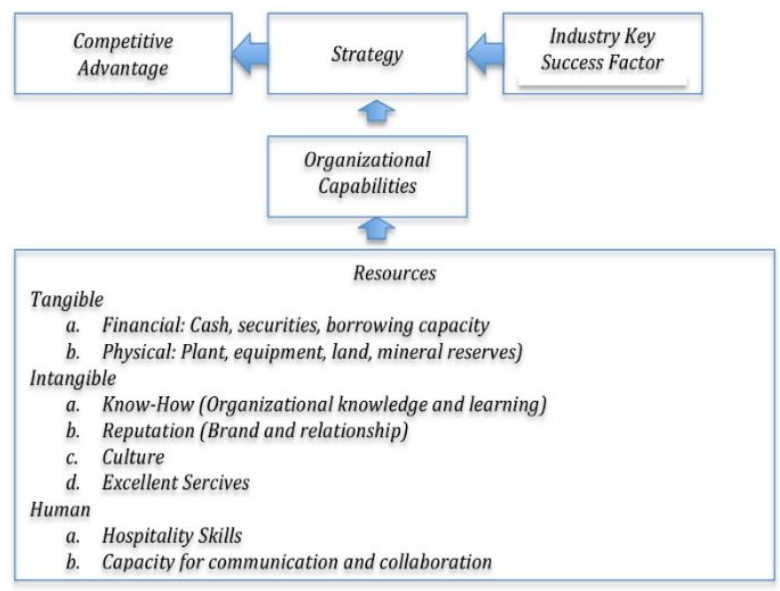

Gambar 6.

Konsep RB V untuk HRME

\section{Analis is Internal}

Dalam melakukan pengembangan resort di kaki Gunung Salak, HRME menggunakan modal sendiri dan pinjaman dari bank. Modal dana yang digunakan sebagian besar adalah milik pribadi, sehingga organisasi tidak terbebani oleh bunga kredit investasi dan organisasi memiliki kondisi keuangan yang aman. Secara umum pendapatan HRME akan terus meningkat, apalagi dengan rencana manajemen untuk membangun hotel dengan kapasitas 160 kamar Tahun 2018. Target pendapatan 2018 bisa mencapai hampir dua kali lipat dibanding tahun 2015.

Dari analisis RBV, fasilitas HRME adalah aset yang paling berharga. Konsep Mongolian Apache di kaki Gunung Salak dengan gaya barrack, treehouse, serta camping adalah nilai yang belum ditiru oleh pesaing. Fasilitas outing, sport, dan outbound di lokasi yang sangat luas serta instagrammable mampu menciptakan pengalaman libur menyenangkan.

Tabel 6.

Matriks EFE HRME

\begin{tabular}{|c|l|c|c|c|}
\hline & \multicolumn{1}{|c|}{ Peluang } & Bobot & Rating & Total \\
\hline 1 & Politik dan keamanan stabil mendukung pariwisata & 0,06 & 2 & 0,12 \\
\hline 2 & Program promosi dan akselerasi pariwisata oleh pemerintah & 0,06 & 2 & 0,12 \\
\hline 3 & Pertumbuhan ekonomi mendorong konsumsi mas yarakat & 0,06 & 3 & 0,18 \\
\hline 4 & Inflasi dan suku bunga mendorong investasi \& konsumsi & 0.12 & 3 & 0,36 \\
\hline 5 & Teknologi digital mendorong akses informasi dan promosi & 0,06 & 4 & 0,24 \\
\hline 6 & Tren MICE \& outbound dalam aktivitas korporasi \& instansi & 0,06 & 4 & 0,24 \\
\hline 7 & Lokasi wisata berkembang dan mudah diakses & 0,06 & 4 & 0,24 \\
\hline
\end{tabular}


Tabel 6. (Lanjutan)

Matriks EFE HRME

\begin{tabular}{|c|l|c|c|c|}
\hline \multicolumn{1}{|c|}{ Peluang } & Bobot & Rating & Total \\
\hline 8 & Akses dan promosi transportasipenerbangan untuk wisata & 0,06 & 2 & 0,12 \\
\hline 9 & Bahan baku bisnis semakin berlimpah & 0,04 & 4 & 0,16 \\
\hline & \multicolumn{1}{|c|}{ Ancaman } & & & 1.78 \\
\hline & \multicolumn{1}{|c|}{ Boting } & Total \\
\hline 1 & Banyak hotel baru berfasilitas MICE di pusat kota & 0,05 & 4 & 0,20 \\
\hline 2 & Kenaikan biaya tetap seperti listrik dan air & 0,02 & 2 & 0,04 \\
\hline 3 & SDM perhotelan yang terbatas kualitas dan kuantitas & 0,06 & 3 & 0,18 \\
\hline 4 & Kenaikan upah minimum UMR & 0,03 & 2 & 0,06 \\
\hline 5 & Isu lingkungan dan pengolahan limbah & 0,02 & 3 & 0,06 \\
\hline 6 & Tuntutan kualitas pelayanan, terutama wisman & 0,06 & 2 & 0,12 \\
\hline 7 & Tingkat hunian kamar bersifat musiman & 0,05 & 2 & 0,10 \\
\hline 8 & Harga cenderung tertekan oleh persaingan & 0,06 & 2 & 0,12 \\
\hline 9 & Loyalitas pelanggan cenderung rendah & 0,07 & 3 & 0,21 \\
\hline & & & & 1.09 \\
\hline
\end{tabular}

Tabel 7.

Matriks IFE HRME

\begin{tabular}{|c|c|c|c|c|c|}
\hline & Kekuatan & RBV/VCA & Bobot & Rating & Total \\
\hline 1 & $\begin{array}{l}\text { Konsep resor alam dan glamping unik kemah Mongoldan } \\
\text { Indian satu-satunya di Indonesia }\end{array}$ & $\begin{array}{l}\text { RBV: Physical } \\
\text { res ources }\end{array}$ & 0,05 & 4 & 0,20 \\
\hline 2 & $\begin{array}{l}\text { Lokasi dekat dengan wisata Gunung Salak dan masih } \\
\text { memiliki lahan yang luas untuk menambah kapasitas resor }\end{array}$ & $\begin{array}{l}\text { RBV: Physical } \\
\text { res ources }\end{array}$ & 0,05 & 4 & 0,20 \\
\hline 3 & $\begin{array}{l}\text { Fasilitas lengkap untuk kegiatan outing dan outbond } \\
\text { perusahaan }\end{array}$ & $\begin{array}{l}\text { RBV: Physical } \\
\text { res ources }\end{array}$ & 0,07 & 4 & 0,28 \\
\hline 4 & $\begin{array}{l}\text { Memiliki kapasitas kamar yang cukup besar untuk rombongan } \\
\text { tamu dalam jumlah besar }\end{array}$ & $\begin{array}{l}\text { RBV: Physical } \\
\text { resources }\end{array}$ & 0,06 & 4 & 0,24 \\
\hline 5 & Memiliki fasilitas standar hotel bintang 4 & $\begin{array}{l}\text { RBV: Physical } \\
\text { res ources }\end{array}$ & 0,07 & 4 & 0,28 \\
\hline 6 & Memiliki fasilitas MICE & $\begin{array}{l}\text { RBV: Physical } \\
\text { res ources }\end{array}$ & 0,07 & 4 & 0,28 \\
\hline \multirow[t]{3}{*}{7} & $\begin{array}{l}\text { Kemampuan keuangan untuk menanggung biaya tetap dan } \\
\text { membangun kapasitas baru }\end{array}$ & $\begin{array}{l}\text { RBV: Financial } \\
\text { res ources }\end{array}$ & 0,07 & 3 & 0,21 \\
\hline & & & & & 1.69 \\
\hline & Kelemahan & RBV/VCA & Bobot & Rating & Total \\
\hline \multirow[b]{2}{*}{1} & \multirow[b]{2}{*}{ Sistem penilaian kinerja (KPI) belum dijalankan } & RBV: Knowhow & \multirow[b]{2}{*}{0,05} & \multirow[b]{2}{*}{1} & \multirow[b]{2}{*}{0,05} \\
\hline & & $\begin{array}{l}\text { (Org. knowledge } \\
\text { \& learning) }\end{array}$ & & & \\
\hline \multirow[t]{2}{*}{2} & \multirow[t]{2}{*}{ Website kurang menarik dan informatif } & $\begin{array}{l}\text { VCA: Sales \& } \\
\text { marketing, \& }\end{array}$ & \multirow[t]{2}{*}{0,04} & \multirow[t]{2}{*}{1} & \multirow[t]{2}{*}{0,04} \\
\hline & & Teknologi & & & \\
\hline \multirow{3}{*}{3} & \multirow{3}{*}{$\begin{array}{l}\text { Pengambilan keputusan strategik terbatas, hanya dilakukan } \\
\text { oleh pemilik }\end{array}$} & VCA: Manajemen & \multirow{3}{*}{0,03} & \multirow{3}{*}{2} & \multirow{3}{*}{0,06} \\
\hline & & SDA \& & & & \\
\hline & & infrastruktur & & & \\
\hline 4 & Biaya tetap tergolong cukup tinggi, yaitu sebesar $65 \%$ & $\begin{array}{l}\text { VCA: Finance } \\
\text { controller }\end{array}$ & 0,05 & 2 & 0,10 \\
\hline 5 & Belum diakreditasi berdasarkan standarusaha hotel & RBV: Knowhow & 0,05 & 2 & 0,10 \\
\hline 6 & Jauh dari pusat Kota Bogor & $\begin{array}{l}\text { RBV: Physical } \\
\text { resources }\end{array}$ & 0,05 & 2 & 0,10 \\
\hline
\end{tabular}


Tabel 7 (Lanjutan)

Matriks IFE HRME (lanjutan)

\begin{tabular}{|c|c|c|c|c|c|}
\hline & Kelemahan & RBV/VCA & Bobot & Rating & Total \\
\hline 7 & Budaya dan perusahaan masih dalam tahap sosialisasi & $\begin{array}{l}\text { RBV: Services } \\
\text { excellence }\end{array}$ & 0,06 & 2 & 0,12 \\
\hline \multirow[b]{2}{*}{8} & \multirow[b]{2}{*}{ Harga kurang kompetitif } & RBV: & \multirow[b]{2}{*}{0,07} & \multirow[b]{2}{*}{2} & \multirow[b]{2}{*}{0,14} \\
\hline & & $\begin{array}{c}\text { Financial } \\
\text { Resources }\end{array}$ & & & \\
\hline \multirow{3}{*}{9} & \multirow{3}{*}{ Kepuasan tamu belum tercapai secara maksimal } & $\begin{array}{l}\text { RBV: Service } \\
\text { excellence, }\end{array}$ & \multirow{3}{*}{0,08} & \multirow{3}{*}{1} & \multirow{3}{*}{0,08} \\
\hline & & $\begin{array}{c}\text { Organizational } \\
\text { capabilities. }\end{array}$ & & & \\
\hline & & VCA: Pelay anan & & & \\
\hline \multirow{4}{*}{10} & \multirow{4}{*}{ Penerapan standarkualitas kurang konsisten } & RBV: Knowhow & \multirow{4}{*}{0,09} & \multirow{4}{*}{1} & \multirow{4}{*}{0,09} \\
\hline & & $\begin{array}{l}\text { (Organizational } \\
\text { knowledge \& } \\
\text { learning, service } \\
\text { excellence, }\end{array}$ & & & \\
\hline & & $\begin{array}{l}\text { Organizational } \\
\text { capabilities. }\end{array}$ & & & \\
\hline & & VCA: Pelay anan & & & \\
\hline & & & & & 0.88 \\
\hline
\end{tabular}

Tabel 8.

Analis is CPM 5 Kompetitor HRME

\begin{tabular}{|l|c|c|c|c|c|c|}
\hline & Novotel & Rancamaya & $\mathbf{1 0 1}$ & Santika & HRME & Salak \\
\hline Kualitas Pelayanan & 0.99 & 0.84 & 0.87 & 0.88 & 0.66 & 0.66 \\
\hline SDM Profesional & 0.40 & 0.27 & 0.35 & 0.38 & 0.27 & 0.27 \\
\hline Lokasi Strategis & 0.13 & 0.13 & 0.19 & 0.26 & 0.17 & 0.23 \\
\hline Fasilitas & 0.81 & 0.74 & 0.52 & 0.44 & 0.74 & 0.44 \\
\hline Jaringan & 0.30 & 0.30 & 0.23 & 0.15 & 0.10 & 0.15 \\
\hline Harga Kompetitif & 0.30 & 0.15 & 0.22 & 0.22 & 0.15 & 0.15 \\
\hline Keuangan & 0.24 & 0.18 & 0.18 & 0.18 & 0.24 & 0.12 \\
\hline Standarisasi & 0.19 & 0.19 & 0.19 & 0.19 & 0.12 & 0.19 \\
\hline TOTAL & $\mathbf{3 . 3 6}$ & $\mathbf{2 . 8}$ & $\mathbf{2 . 7 5}$ & $\mathbf{2 . 7}$ & $\mathbf{2 . 4 5}$ & $\mathbf{2 . 2 1}$ \\
\hline
\end{tabular}

Manajemen resort memiliki

kemampuan dan pengetahuan bidang

perhotelan, kompetensi umum dan kemampuan

teknis dalam pengetahuan tentang service

excellent, pengetahuan tentang keuangan,

pemasaran, food \& beverages dan pengetahuan

tentang keunikan hotel mereka. Modal pengetahuan dan kemampuan tersebut akan membuat operasional HRME dapat berjalan dengan baik dan dapat menjadi sebuah sumber daya yang luar biasa dalam pengembangan bisnis. Dukungan budaya yang kuat juga menciptakan etos kerja yang baik. 
Bagian yang perlu ditingkatkan adalah manajemen biaya serta manajemen merek. Biaya tetap yang tinggi mendorong perusahaan harus melakukan efisiensi untuk menurunkan breakeven point, juga perlu meningkatkan economics of scale-nya dengan menyasar segmen potensial yang lebih menarik.

Merek HRME juga belum cukup dikenal dengan baik. Asosiasi yang dekat dengan HRME adalah hotel resort, outdoor, outing, sport, Mongolian, Apache. Di antara sekian asosiasi tersebut, HRME masih kalah dengan hotel lain seperti Rancamaya dan Novotel. Perlu pengelolaan lebih kuat dalam brand awareness HRME. HRME memiliki kemampuan mengelola aset tangible dan intangible yang baik sehingga mampu melayani: (1) Persiapan kamar dalam jangka waktu maksimal 20 menit; (2) Room service order dalam jangka waktu maksimal 30 menit; (3) Proses check in dan check out dalam jangka waktu maksimal 10 menit per tamu.

Sementara itu, melalui analisis rantai nilai. Terhadap beberapa titik aktivitas yang kurang optimal, antara lain: (1) Sales dan marketing belum maksimal dalam promosi kepada calon konsumen. Keunikan model

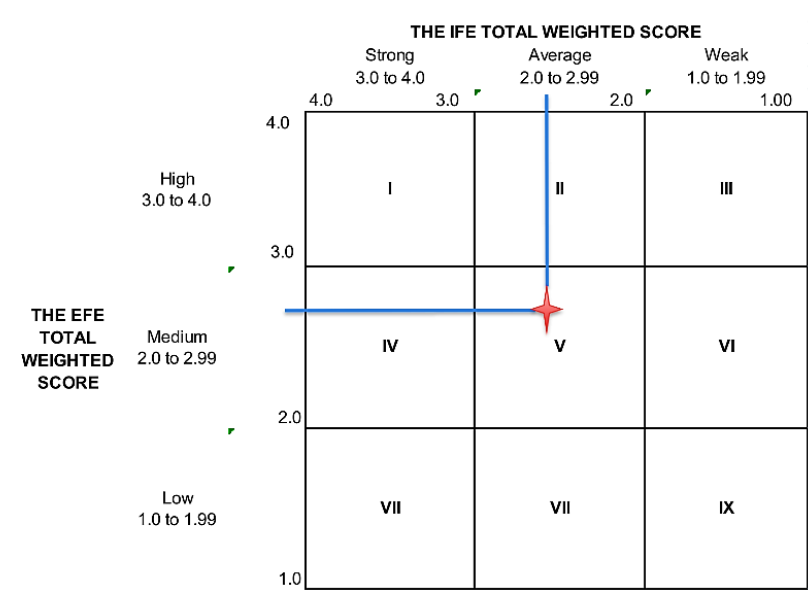

Gambar 7. Posisi Matriks IE HRME

kemah Mongol dan Indian satu-satunya di Indonesia belum terjual dengan maksimal; (2) Karyawan di dalam aktivitas pelayanan perlu lebih terinernalisasi nilai-nilai perusahaan; (3) Pengembangan teknologi HRME untuk meningkatkan visibility, awareness, dan efficiency. Tidak hanya pada situs online/mobile booking, namun juga kaitannya dengan media sosial; (4) Selama ini belum ada sistem penilaian kinerja, program pelatihan, dan pengembangan karyawan.

Dari analisis CPM di atas, diperoleh bahwa faktor kualitas pelayanan sangat tinggi peranannya pada semua kompetitor, diikuti fasilitas dan SDM professional. Pada HRME, faktor tertinggi diperoleh dari fasilitas, sementara itu faktor terlemah ada pada jaringan dan standarisasi. 
Selanjutnya, dalam analisis Matriks

IFE, dapat dikenali 7 faktor kekuatan dan 10 faktor kelemahan. Skor akhir yang diperoleh adalah 2.54, yang artinya kemampuan perusahaan mengelola kekuatan dan kelemahan berada pada rentang rata-rata. Faktor kekuatan terbaik dimiliki pada fasilitas bintang 4 , fasilitas MICE, dan fasilitas outing outbound. Sementara kelemahan terbesar terdapat pada website dan dukungan IT serta sistem penilaian kinerja.

Pada Matriks IE, HRME berada pada kuadran $\mathrm{V}$ yang merupakan kuadran dengan strategi hold and maintain. Strategiyang dipilih dalam kuadran tersebut adalah penetrasi pasar, pengembangan produk.

Dua strategi besar ini menjadi alat klasifikasi dari strategi dan inisiatif strategi yang muncul pada Matriks TOWS. Beberapa langkah penetrasi pasar yang bisa dilakukan:

(1) Penawaran khusus bagi konsumen grup; (2)

Perluas kemitraan dalam rantai nilai; (3) Penawaran khusus untuk kegiatan MICE, Outing, dan Outbound; (4) Meningkatkan kegiatan networking; (5) Promosi melalui media digital; (6) Kampanye korporat atas kepedulian sosial dan lingkungan;

Sinkronisasi kegiatan promosi dengan hari libur, hari besar, dan hari peringatan di Kota Bogor.

Sementara itu, inisiatif strategi pengembangan produk adalah: (1) Pembuatan website dan booking online pribadi; Pembangunan fasilitas outbound yang lebih memacu adrenaline; (3) Penambahan kapasitas kamar.

$$
\text { Sedangkan inisiatif strategi }
$$

pendukungnya: (1) Peningkatan kapasitas manajemen sumber daya insani;

Peningkatan kemampuan pelayanan;

Internalisasi budaya; (3) Pelatihan dan pengembangan karyawan.

Jika strategi yang disusun berbasis strength-based maka prioritas akan diletakkan pada penetrasi pasar. Hal ini juga disetujui oleh pihak manajemen dan pemilik perusahaan. Hasil yang sama juga muncul pada analisis QSPM. Diperoleh pula bahwa prioritas HRME ada pada penetrasi pasar. Perusahaan perlu segera mengimplementasikan aktivitas real yang mendukung penetrasi pasar.

Kegiatan kemitraan, networking, serta pemanfaatan media sosial menjadi langkahlangkah yang perlu ditempuh oleh HRME. Hal ini juga didukung dengan kampanye korporat yang mulai dibangun. Pada sisi promosi, 
berbagai paket penawaran perlu dikembangkan

oleh HRME. Posisi harga yang terlalu tinggi dengan brand awareness yang belum

kuat menjadi alasan utama tingkat okupansinya

tidak sesuai harapan.

Tabel 9.

Matriks TOWS

\begin{tabular}{|c|c|c|}
\hline & SO Strategies & WO Strategies \\
\hline $\begin{array}{l}\text { Politik dan keamanan stabil } \\
\text { mendukung pariwisata }\end{array}$ & Penawaran khusus bagi konsumen grup & $\begin{array}{l}\text { Pengembangan produk, } \\
\text { Pengembangan website, online } \\
\text { booking, \& infrstruktur TI }\end{array}$ \\
\hline $\begin{array}{l}\text { Program promosi dan } \\
\text { akselerasi pariwisata oleh } \\
\text { pemerintah }\end{array}$ & $\begin{array}{l}\text { Perluasan kemitraan dalam rantai nilai, } \\
\text { sinkronisasi kegiatan }\end{array}$ & $\begin{array}{l}\text { Perbaikan kualitas pelayanan dan } \\
\text { penyediaan fasilitas }\end{array}$ \\
\hline $\begin{array}{l}\text { Pertumbuhan ekonomi } \\
\text { mendorong konsumsi } \\
\text { masyarakat }\end{array}$ & $\begin{array}{l}\text { Promosi digital, sale blitz, \& word to } \\
\text { mouth marketing }\end{array}$ & $\begin{array}{l}\text { Pengembangan produk berbasis } \\
\text { lokasi }\end{array}$ \\
\hline $\begin{array}{l}\text { Tingkat inflasi menurun dan } \\
\text { meningkatkan dayabeli }\end{array}$ & $\begin{array}{l}\text { Penawaran khusus korporasi \& instansi } \\
\text { untuk MICE, outing, dan outbond }\end{array}$ & $\begin{array}{l}\text { Improvisasi kamar dan fasilitas, } \\
\text { peningkatan kapasitas kamar }\end{array}$ \\
\hline $\begin{array}{l}\text { Tingkat SBI cenderung stabil } \\
\text { dan menggerakkan investasi }\end{array}$ & Peningkatan kapabilitas finansial & Akreditasi standarusaha hotel \\
\hline $\begin{array}{l}\text { Teknologi digital mendorong } \\
\text { akses informasi dan promosi }\end{array}$ & Peningkatan teknologi \& konten website & Peningkatan kapasitas manajemen \\
\hline \multirow[t]{2}{*}{$\begin{array}{l}\text { Tren MICE dan kegiatan } \\
\text { Outbond yang diadakan } \\
\text { perusahaan dan instansi }\end{array}$} & $\begin{array}{l}\text { Membangun fasilitas outbond terbaru \& } \\
\text { menantang }\end{array}$ & Pengembangan produk \\
\hline & ST Strategies & WT Strategies \\
\hline $\begin{array}{l}\text { Banyak hotel dengan fasilitas } \\
\text { MICE yang berada di pusat } \\
\text { Kota }\end{array}$ & Paket kegiatan MICE & $\begin{array}{l}\text { Sistem penilaian kinerja yang } \\
\text { direlasikan dengan tingkat } \\
\text { kepuasan konsumen }\end{array}$ \\
\hline Kenaikan biaya tetap & Peningkatan kapabilitas finansial & Peningkatan kapasitas manajemen \\
\hline $\begin{array}{l}\text { SDM di bidang perhotelan } \\
\text { (kuantitas) terbatas }\end{array}$ & Perekrutan SDM berkualitas & Pelatihan internal \\
\hline $\begin{array}{l}\text { SDM di bidang perhotelan } \\
\text { (kualititas) terbatas }\end{array}$ & Internalisasi nilai dan budaya & Perekrutan SDM berpengalaman \\
\hline Kenaikan UMR & $\begin{array}{l}\text { Efisiensi keuangan, Internalisasi nilai } \\
\text { dan budaya }\end{array}$ & Efisiensi pada biaya tetap \\
\hline $\begin{array}{l}\text { Isu lingkungan atas } \\
\text { pengelolaan dan pengolahan } \\
\text { limbah }\end{array}$ & $\begin{array}{l}\text { Melakukan networking dengan } \\
\text { konsumen utama }\end{array}$ & $\begin{array}{l}\text { Program CSR \& kampanye } \\
\text { korporat }\end{array}$ \\
\hline
\end{tabular}




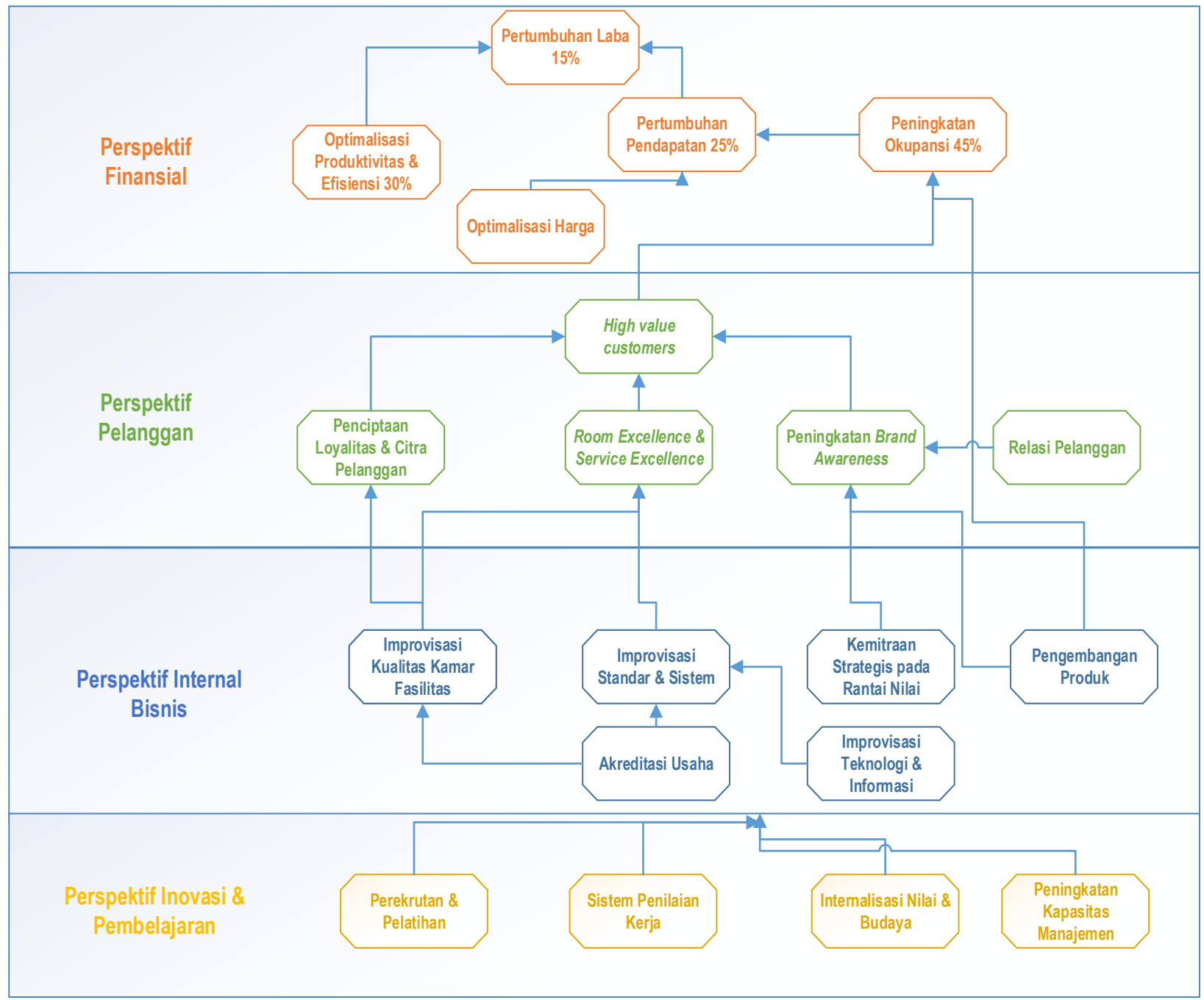

Gambar 8.

Peta Strategi HRME

Dalam perspektif Balance Scorecard, tergambar hubungan antar satu inisiatif strategi dengan inisiatif yang lain. Profitabilitas naik $15 \%$ adalah target yang cukup realistis, seiring dengan upaya peningkatan volume penjualan sebesar $25 \%$ dan diiringi produktivitas serta efisiensi biaya hingga $30 \%$.

Peningkatan profit tidak ditargetkan terlalu besar karena HRME pun masih dalam pembenahan sistem dan prosedur kerja serta masih ada keinginan untuk membangun hotel dan apartemen. Akan dilakukan efisiensi biaya tetap sebesar $2 \%-5 \%$ per tahun. Selain itu akan dilakukan fungsi kontrol terhadap beban pokok divisi kamar, makanan dan minuman, beban peralatan, pemeliharaan dan energi, beban umum dan administrasi. 
Pendapatan HRME terbesar berasal dari perusahaan swasta dan pemerintah. Pelanggan eksisting ini memiliki kesesuaian dengan harga dan manfaat yang ditawarkan HRME. Melalui percepatan yang akan dilakukan oleh tim sales \& marketing dengan program sale blitz, presentasi ke konsumen eksisting potensial, dan media promosi outdoor di jalan tol Jagorawi arah exit Bogor, launching website booking online perusahaan dan sarana booking online seperti Agoda dan Traveloka tentunya akan mampu mencapai tingkat okupansi sebesar 45\%. Kegiatan korporat berupa seminar, training, dan pelatihan, outing, dan outbound menjadi target utama HRME.

Program promosi seperti kampanye korporat serta program promo media sosial ditujukan untuk meningkatkan brand awareness tidak hanya pelanggan eksisting namun juga kepada segmen yang lebih luas. Segmen lain yang tidak menutup kemungkinan adalah wisatawan mancanegara serta wisatawan kelas menengah ke atas. Pada segmen ini, program promosi secara perlahan ditingkatkan, paket harga dan benefit yang ditawarkan perlu secara perlahan dibuat melalui pengembangan inovasi produk.

\section{KESIMPULAN DAN SARAN}

Hotel Resort HRME memiliki diferensiasi yang luar biasa dengan konsep Mongolian Apache. Sistem internal SDM yang belum matang serta strategi pemasaran yang belum terintegrasi menjadikan target penjualan tidak tercapai, pun dibarengi pula dengan inefisiensi pada berbagai komponen biaya. Posisi HRME belum cukup kompetitif dibandingkan dengan pesaing sehingga HRME perlu melakukan formulasi strategi agar lebih terarah menuju visi-misi yang diharapkan.

Strategi penetrasi pasar perlu dikembangkan oleh HRME dengan menerapkan pemasaran yang lebih agresif dan sesuai dengan kebutuhan pelanggan terbesar yakni perusahaan swasta dan pemerintah.

Brand awareness menjadi kunci utama bagi HRME untuk meningkatkan target penjualan hingga 25\%. Masalah brand awareness ynag dialami oleh perhotelan juga ditemui dalam Fadmawati (2011). Strategi di atas perlu didukung dengan pengembangan produk yang juga menyasar segmen lebih luas 
seperti wisman dan wisatawan menengah ke atas. Tentunya didukung dengan penguatan kapabilitas internal modal insani. Dengan demikian profitabilitas perlahan dapat naik hingga 15\% sampai tahun 2021 nanti.

Riset ini cukup terbatas dengan menggunakan data sekunder dan analisis internal perusahaan. Perlu didukung dengan analisis perilaku pelanggan dan tren bisnis ke depan, jika nantinya diharapkan bentuk rincian strategi penetrasi pasar dan pengembangan produk yang lebih detail dapat disusun.

Penelitian ini juga dimungkinkan menjadi rujukan bagi riset-riset serupa terutama dalam industri perhotelan di Indonesia yang mengalami perkembangan positif sejak tahun 2011 hingga 2017. Beberapa hal yang dapat diuji kembali oleh peneliti lain adalah temuan key successfactors di industriperhotelan, selain juga penggunaan analisis RBV dan analisis value chain. Analisis RBV dan value chain menjadi lebih lengkap jika diketahui jejak rincian biaya setidaknya selama 5 tahun agar diketahui pola dan struktur biaya.

Perspektif Balance Scorecard ikut membantu penyusunan strategi menjadi lebih mudah dipahami oleh seluruh unit departemen di perusahaan, namun dalam pelaksanaannya, akan berdampak pada sistem SDM perusahaan. Sehingga sistem SDM perlu disempurnakan dan kapabilitas karyawan perlu ditingkatkan agar dapat memahami dan menerapkan peta strategi dengan efektif efisien.

Adanya model bisnis baru seperti AirBnB serta model bisnis semi konvensional seperti serviced apartment, condotel, dan condominium, serta themepark hotel maupun model bisnis yang agak terselubung seperti kamar sewa menjadi tantangan tersendiri bagi pelaku bisnis perhotelan konvensional. Dalam hal ini, model analisis 5 forces Porter menjadi agak sulit dilakukan. Diperlukan model analisis lain untuk mendukung formulasi strategi. Namun secara keseluruhan, metodologi David (2011) cukup mumpuni dalam penyusunan formulasi strategi. 


\section{DAFTAR PUSTAKA}

Agoda. 2016. Top Choice of Agoda Travelers 2016. Informasi dapat diakses di: https://www.agoda.com/the-1o1-bogor-suryakancana-hotel/hotel/bogor-id.html?cid=-146

Amir, M., T. 2011. Manajemen Strategik: Konsep dan Aplikasi. Jakarta: Rajagrafindo Persana.

Balance Scorecard Institute (BSI). (n.d.). Evaluation of a BSC System \& Its Implementation. Diakses di: https $/ /$ www.balancedscorecard.org/portals/0/pdf/Evaluation_Step_9_CR2.pdf

Barney, J. B. 1991. Firm Resources and Sustained Competitive Advantage. Journal of Management, Vol. 17, pp. 99-120.

Biro Pusat Statistik [BPS]. (n.d.). Jumlah Akomodasi, Kamar, dan Tempat Tidur yang Tersedia pada Hotel Bintang Menurut Provinsi, 2000-2016. Dapat Diakses di: https://www.bps.go.id/linkTableDinamis/view/id/1096

Biro Pusat Statistik [BPS]. 2016. Dapat Diakses di: www.bps.go.id

David, F. R., \& David, F. R. 2014. External Audit in Strategic Management Concepts (15th Edition). London: Pearson Education Limited.

David, F. R., 2011. Strategic Management (13th Ed.). New Jersey: Pearson Education, Inc.

Dinas Pariwisata dan Kebudayaan [Disparbud]. (2016). Dokumen Renstra, dapat diakses di: http://disparbud.kotabogor.go.id/page/show/rensta

Dotson et al. 2016. Brand Attitudes and Brand Search. Google Research. Dapat diakses: https://research.google.com/pubs/archive/45740.pdf

Drucker, Peter F. 2008. Management (Revised Edition). HarperBusiness.

Fadmawati, D. Kadek, 2011. Reformulasi Strategi Pemasaran untuk Meningkatkan Occupancy room rate di Hotel Four Seasons Hotel Jimbaran Bali. Universitas Udayana, Denpasar.

Hansen, D., R, \& Mowen, M., M. 2003, Management Accounting (Sixth Edition). SouthWestern.

Henry, A. 2007. Understanding Strategic Management. Oxford: Oxford University Press.

Herlambang, V. 2016. Developer Menyerbu Bogor Buat Bangun Hotel. Dikutip dari Kontan. Dapat diakses melalui: http://industri.kontan.co.id/news/developer-menyerbu-bogor-buat-bangun-hote 1 
Kaplan, R., Norton, D, 2004. Strategy Map Converting Intangible Assets Into Tangible Outcome, Harvard Business School Press, Boston.

Kementerian Pariwisata. 2015. Laporan Akuntabilitas Kinerja Kementerian Pariwisata tahun 2015. Dapat diakses di: www.kemenpar.go.id/userfiles/file/test/LAKIP-KEMENPAR\%202015.pdf

Kementerian Pariwisata (n.d.). Statistik Tingkat Penghunian Kamar Hotel Bintang Tahun 20142017. Dapat diakses di: $\underline{w w w . k e m e n p a r . g o . i d / a s p / r i n g k a s a n} . a s p ? c r h a l=1 \& c=113 \& r e f=$

Kompas. 2015. Pertumbuhan Hotel Berbintang di Bogor Dua Kali Lipat. Informasi dapat diakses melalui:

http://properti.kompas.com/read/2015/01/14/184604121/Pertumbuhan.Hotel.Berbintang.di.Bogor.Dua $\underline{\text { Kali.Lipat. }}$

Pemerintah Kabupaten Bogor, 2015. Dispenda Tahun Ini Targetkan PAD Sebesar Rp 1,75 Triliun. 18 Agustus, 2016, dari https://bogorkab.go.id/index.php/post/detail/2134/dispenda-tahuninitargetkan-pad-sebesar-rp-1-75-triliun\#.WEnvmqJ95-U

Pemerintah Kota Bogor. 2003. Profil Investasi Bidang Pariwisata Kota Bogor. Informasidapat diakses melalui: http://kotabogor.go.id/index.php/page/detail/125/pariwisata\#.WmraRUxuJO8

Pemerintah Kota Bogor. 2016. Jumlah Wisatawan 2017 Diprediksi Naik. Informasi dapat diakses di: http://kotabogor.go.id/index.php/show_post/detail/5721/jumlah-wisatawan-2017diprediksi-naik\#.WmrbX0xuJO8

Pemerintah Kota Bogor. 2017. Pengembangan Pariwisata Perlu Dukungan Pentahelix. Informasi dapat diakses melalui:

http://kotabogor.go.id/index.php/show_post/detail/6446/pengembangan-pariw isata-perlu-dukunganpentahelix\#.Wmrbi0xuJO8

Pemerintah Kota Bogor. 2017. Kunjungan Wisatawan Dongkrak PAD. Informasi dapat diakses di: http://kotabogor.go.id/index.php/show_post/detail/8697/kunjungan-wisatawan-dongkrakpad\#.WmrbkkxuJO8

Pemerintah Kota Bogor. 2017. Kota Bogor Menjadi Destinasi Wisata Favorit Kuliner dan Pariwisata. Informasi dapat diakses di: 
http://kotabogor.go.id/index.php/show_post/detail/8697/kunjungan-wisatawan-dongkrakpad\#.WmrbkkxuJO8

Porter, M., \& Magretta, J. 2014. Strategy and Competition: The Porter Collection. Boston: Harvard Business Review Press.

Prayoga, D. 2017. Tingkat Okupansi Capai 80 Persen. Dikutip dari Radar Bogor. Dapat diakses: www.radarbogor.id/2017/11/02/tingkat-okupansi-capai-80-persen/

Nurhayati, 2017. Release Kominfo Kabupaten Bogor. Dapat diakses di: http://kecamatanciampea.bogorkab.go.id/index.php/post/detail/7604/disbudpar-ajak-perswisata\#.WmrT5KiWZJ8 atau http://nasional.republika.co.id/berita/nasional/daerah/17/05/03/opctr3365-bupati-bogor-klaim$\underline{\text { sumbang-10-persen-wisatawan-mancanegara }}$

Sammut-Bonnici, T., \& Galea, D. 2015. Wiley Encyclopedia of Management. John Wiley \& Sons, Ltd.

Schonberger, Richard J. 1997. World Class Manufacturing. Jakarta: Prenhallindo.

Sulastiyono, Agus, 2008. Manajemen Penyelenggaraan Hotel. Cetakan Keenam. Bandung : Alfabeta.

Wernerfelt, B. 1984. A Resource-based View of The Firm. Strategic Management Journal, Vol. 5, pp. 171-180.

Wibisono, 2006. Manajemen Kinerja: Konsep Desain dan Teknik Meningkatkan Daya Saing Perusahaan. Jakarta: Erlangga.

Zikmund, W.G., Babin, J., Carr, J. \& Griffin, M. 2012. Business Research Methods. Cengage Learning.

Situs website www.traveloka.com

Situs website Google trends.google.com

Situs website www.bi.go.id

(Semua situs telah diakses kembali terakhir pada 26 Januari 2018) 